\title{
KEANEKARAGAMAN ORGANISME PADA RHIZOSFER GULMA SIAM DI LAHAN VULKANIK, PESISIR, DAN KARST
}

\author{
(ORGANISM DIVERSITY IN THE RHIZOSPHERE OF SIAM WEEDS \\ IN VOLCANIC, COASTAL AND KARST LAND)
}

\author{
Tien Aminatun, Siti Umniyatie, Anna Rakhmawati, Aji Suhandy, Nrangwesthi \\ Widyaningrum, dan Kurnia Cahyani \\ Fakultas Matematika dan Ilmu Pengetahuan Alam, Universitas Negeri Yogyakarta \\ J1. Colombo No 1, Karangmalang, Depok, Sleman, Daerah Istimewa Yogyakarta, Indonesia. \\ email: tien_aminatun@uny.ac.id
}

\begin{abstract}
Abstrak
Penelitian ini bertujuan untuk membandingkan kondisi edafik, hubungan antara kondisi edafik dan keanekaragaman organisme tanah, serta perbedaan keanekaragaman organisme tanah pada berbagai ekosistem rhizosfer gulma Siam (Chromolaena odorata) yang tumbuh di lahan vulkanik, pesisir, dan karst. Penelitian dilakukan dengan mengambil sampel tanah dari ekosistem rhizosfer gulma Siam di lahan vulkanik, karst, dan pesisir Daerah Istimewa Yogyakarta; mengamati komposisi organisme tanah di laboratorium, yaitu collembola, nematoda, dan mikoriza. Hasil penelitian menunjukkan bahwa tanah pada rhizosfer gulma Siam yang tumbuh di lahan karst menunjukkan tingkat kesuburan tertinggi yang ditunjukkan oleh kandungan $\mathrm{N}$, K, dan C-organik tanah, sedangkan tanah pesisir memiliki kandungan $\mathrm{P}$ tertinggi. Tekstur tanah pada rhizosfer gulma Siam lebih berpengaruh terhadap keanekaragaman organisme tanah dibandingkan kandungan hara tanah dan sifat tanah lainnya yang diteliti. Keragaman organisme tanah rhizosfer gulma Siam lebih besar di lahan pesisir dibandingkan di lahan karst dan vulkanik. Implikasi dari hasil tersebut adalah bahwa tanah dengan tekstur berpasir akan lebih bermanfaat bagi pertumbuhan gulma Siam dengan keanekaragaman organisme rhizosfer yang lebih tinggi.
\end{abstract}

Kata kunci: Chromolaena odorata, kondisi edafik, lahan karst, rhizosfer

\begin{abstract}
The research aims to compare the edaphic condition, the relationship between the edaphic condition and soil organism diversity, and the differences of soil organism diversity in different rhizosphere ecosystems of Siam weed growing in volcanic, coastal and karts areas. The research was conducted by taking soil samples from the Siam weed rhizosphere ecosystems in volcanic, karst and coastal areas of the Special Region of Yogyakarta and observing the composition of the soil organisms in the laboratory, including collembola, nematode, and mycorrhiza. The results find that soil from rhizosphere of Siam weed growing in karst area shows the highest level of fertility indicated by the N, K, and C-organic contents of the soil, whereas soil from coastal area has the highest P content. Soil texture in the rhizosphere of Siam weed has more effect on the diversity of soil organisms than the soil nutrient content and other soil properties investigated. The diversity of soil organisms of Siam weed rhizosphere is greater in coastal area than those in karst and volcanic areas. The implication of the results is that soil with a sandy texture will be more beneficial for the growth of Siam weed with a higher diversity of rhizosphere organisms.
\end{abstract}

Keywords: Chromolaena odorata, edaphic condition, karst area, rhizosphere 


\section{PENDAHULUAN}

Gulma Siam (Chromolaena odorata) merupakan gulma terestrial invasif terburuk di daerah tropis dan subtropis yang sulit dikendalikan. Tanaman ini memiliki sifat yang sangat kompetitif dan tahan terhadap kondisi kering yang ekstrim (te Beest et al., 2013) dan mudah tumbuh di berbagai jenis tanah, bahkan di tanah kering (Zachariades et al., 2009). Resistensi terhadap kondisi ini dimungkinkan karena sistem perakarannya yang baik.

Sistem perakaran sangat menentukan produktivitas suatu tanaman. Banyaknya akar mempengaruhi efektivitas penyerapan air, hara dan senyawa volatil. Akar juga melepaskan eksudat sebagai sumber substrat dan energi untuk organisme rhizosfer (Gregory, 2006). Eksudat akar dapat mempengaruhi kandungan nitrogen pada tanah sekitarnya (Castoldi et al., 2013), bekerja sama dengan siderofor yang dihasilkan oleh mikroba rhizosfer yang membantu efektivitas penyerapan zat besi (Nuzzo et al., 2018), bersifat alelopatik atau menekan pertumbuhan tumbuhan lain di sekitarnya (Wardani et al., 2018), serta mempengaruhi perilaku dan perubahan komposisi organisme rhizosfer sebagai respons terhadap eksudat (Rasmann et al., 2012).

Organisme rhizosfer bertindak sebagai agen perubahan fisik, kimia, dan biologi di dalam tanah. Mereka berinteraksi satu sama lain dan berkontribusi dalam agregasi tanah (Lehmann et al., 2017). Aktivitas mikroorganisme rhizosfer juga memberikan manfaat bagi tanaman melalui sintesis fitohormon, pelarutan mineral, produksi siderofor, peningkatan serapan hara, luas daun, klorofil, dan kandungan protein terlarut daun, serta menghasilkan enzim antioksidan untuk melindungi tanaman dari tekanan lingkungan yang dapat menyebabkan kerusakan sel (FloresGallegos \& Nava-Reyna, 2018). Oleh karena itu, keanekaragaman organisme rhizosfer merupakan komponen yang sangat penting dalam biologi tanah dan perlu dipelihara. Keanekaragaman spesies dan tipe interaksi berperan penting dalam menjaga keanekaragaman hayati suatu ekosistem (Mougi \& Kondoh, 2012).

Studi tentang hubungan fungsional antara keanekaragaman organisme tanah dengan ekosistem tanah masih sangat terbatas, terutama karena setiap lokasi memiliki keanekaragaman organisme tanah dan peran yang berbeda-beda. Oleh karena itu, penting untuk mengidentifikasi pola umum makroekologi yang berkaitan dengan sebaran dan fungsi organisme tanah (Guerra et al., 2020). Pada penelitian ini organisme tanah di rhizosfer gulma Siam yang diteliti adalah Vesicular Arbuscular Mycorrhiza (VAM), nematoda, dan collembola. 
VAM adalah mikroorganisme rhizosfer yang penting. Banyak tumbuhan yang memiliki hubungan endosimbiosis dengan VAM untuk meningkatkan mekanisme pertahanan terhadap serangan parasit (Miyata et al., 2014), meningkatkan penyerapan hara (Buendia et al., 2016), dan meningkatkan serapan air dan hara mineral oleh akar tanaman dengan cara merangsang pertumbuhan dan percabangan akar (Maillet et al., 2011).

Nematoda berperan penting dalam mengatur siklus biogeokimia dan dinamika komunitas vegetasi serta merupakan indikator aktivitas biologi tanah (van den Hoogen et $a l .$, 2020). Nematoda juga paling melimpah di ekosistem tanah, karena kemampuannya memakan berbagai sumber makanan di dalam tanah, berkembang biak dengan cepat dan bertahan dalam kondisi lingkungan yang kontras (Schratzberger et al., 2019). Interaksi antara nematoda parasit dan mikroba tanah dapat memperparah serangan penyakit akar (Kanfra et al., 2018). Interaksi nematoda dengan bakteri pelarut fosfat dapat mempengaruhi ketersediaan $\mathrm{P}$ dalam tanah (Irshad \& Yergeau, 2018); meningkatkan ketersediaan N, P, dan unsur hara dalam tanah sehingga secara signifikan meningkatkan produksi biomassa tanaman (Gebremikael et al., 2015). Selain itu, nematoda juga merupakan bioindikator penting perubahan lingkungan dan kondisi tanah, karena sedikit perubahan pada sifat tanah akibat perubahan iklim dapat menyebabkan perubahan besar pada komunitas nematoda tanah (Sun et al., 2013).

Collembola merupakan detritivora penting, karena dapat mempengaruhi pertumbuhan tanaman, konsentrasi hara pada jaringan dan ekspresi gen pada tanaman. Collembola di rhizosfer meningkatkan pertahanan tanaman terhadap jamur dan herbivora (Graf et al., 2019). Collembola juga dapat berperan dalam merehabilitasi lahan yang rusak, karena dapat berperan sebagai spesies pionir (Vanhée \& Devigne, 2018).

Penelitian keanekaragaman organisme tanah pada ekosistem rhizosfer gulma Siam yang tumbuh di berbagai lahan, dalam hal ini diwakili oleh lahan vulkanik, pesisir, dan karst, dengan jenis dan sifat tanah yang berbeda menjadi penting untuk dilakukan. Berbagai hasil penelitian menunjukkan bahwa perbedaan kondisi tanah dan lingkungan mempengaruhi keanekaragaman organisme tanah, antara lain VAM, nematoda, dan collembola. Keanekaragaman VAM dipengaruhi oleh perubahan musim dan jenis tanah (Kartika, Duaja, \& Gusniwati, 2019). Penggunaan lahan dan tipe vegetasi mempengaruhi komposisi spesies, keanekaragaman VAM, dan kepadatan spora (Sarkar et al., 2014). Sifat kimia tanah seperti C, N, $\mathrm{P}$, dan logam berat berkontribusi terhadap kepadatan; sedangkan keragaman spora 
VAM, kandungan $\mathrm{C}$ dan $\mathrm{N}$ berkorelasi negatif dengan kepadatan spora (Husna et al., 2015). Ketinggian berhubungan dengan jenis infeksi, ukuran populasi dan persentase infeksi VAM (Marizal et al., 2017). Kelimpahan nematoda menunjukkan korelasi positif terhadap karbon organik tanah dan nitrogen (Treonis et al., 2018). Invasi collembola dipengaruhi oleh kondisi dan kandungan nutrisi seresah yang menunjukkan adanya interaksi antara komposisi seresah dengan aktivitas collembola (Leinaas et al., 2015). Pengolahan tanah secara signifikan mengurangi kelimpahan invertebrata tanah dan berdampak negatif pada degradasi tanah primer dan sekunder (Liu et al., 2016). Kepadatan mikroarthropoda menurun seiring dengan peningkatan kedalaman dan elevasi tanah, terutama karena ketersediaan bahan organik (Illig et al., 2010). Ekosistem tanah yang terbentuk dengan pengaruh antropogenik namun memiliki kandungan bahan organik yang tinggi dapat menjadi habitat yang baik bagi organisme tanah khususnya cacing dan collembola (Kolesnikova et al., 2019).

Penelitian tentang hubungan antara pertumbuhan gulma Siam di berbagai kondisi bentuk lahan dengan keanekaragaman organisme tanah yang hidup di ekosistem rhizosfer gulma Siam belum pernah dilakukan. Hasil penelitian ini diharapkan dapat mendukung informasi terkait sifat invasif gulma Siam di berbagai bentang alam. Oleh karena itu, penelitian ini bertujuan untuk mengetahui: kondisi edafik pada ekosistem rhizosfer gulma Siam yang tumbuh di lahan vulkanik, pesisir, dan karst; hubungan keanekaragaman organisme tanah (collembola, nematoda, dan mikoriza) dengan kondisi edafik; dan perbedaan struktur komunitas organisme tanah (collembola, nematoda, dan mikoriza) pada ekosistem rhizosfer gulma Siam yang berbeda.

\section{METODE}

Eksplorasi lapangan dilakukan di lahan vulkanik, karst dan pesisir Daerah Istimewa Yogyakarta (Gambar 1). Objek penelitian adalah organisme tanah, yaitu komunitas nematoda, collembola, dan VAM yang terdapat di ekosistem rhizosfer gulma Siam yang tumbuh di lahan vulkanik, karst dan pesisir. Variabel penelitian ini adalahjenis lahan meliputi lahan vulkanik, karst, dan pesisir; sifat edafik tanah yang terdiri dari kandungan $\mathrm{N}, \mathrm{P}, \mathrm{K}$, bahan organik, kelembaban, suhu, dan $\mathrm{pH}$ tanah; dan struktur komunitas nematoda, collembola, dan VAM.

Peralatan penelitian meliputi alat-alat yang digunakan untuk melakukan sampling tanah, ekstraksi dan isolasi nematoda dan VAM, pengukuran morfologi collembola, identifikasi nematoda (Mai \& Lyon, 1975), mikroskop, dan optilab. Pengumpulan data 


\section{Gambar 1 \\ Lokasi Pengambilan Sampel: Titik 1 Lahan Vulkanik (7 38'31.9 "LS, 110 25'42.3" BT); Titik 2 Lahan Pesisir ( $8^{\circ} 00^{\prime} 34.8$ “ $S, 110^{\circ} 17^{\prime} 58.0^{\prime}$ ” E); Titik 3 lahan karst (7 58 '39.8 “S, $110^{\circ} 22$ '34.4” BT)}

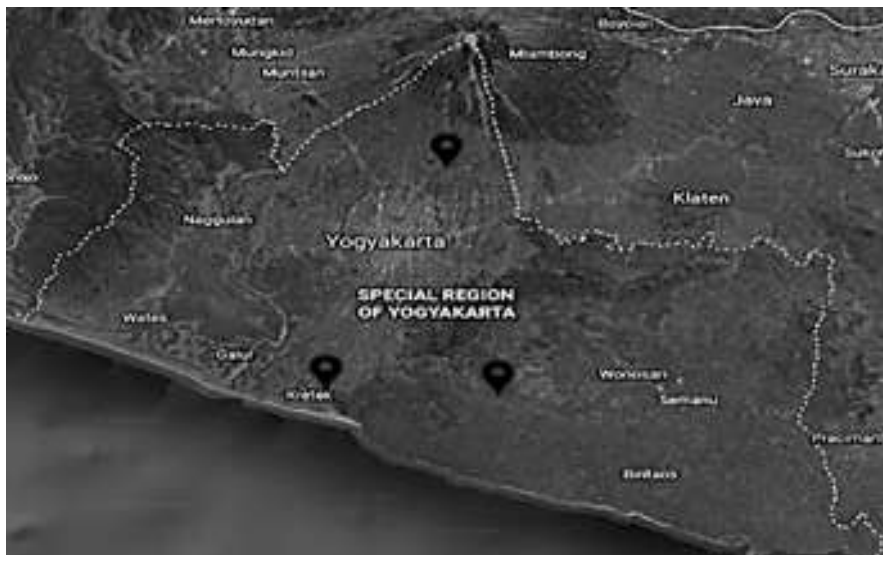

dibagi menjadi beberapa tahap. Pertama, memilih tanaman gulma siam. Dalam hal ini, gulma Siam yang dipilih memiliki tinggi sekitar 1 sampai 1,5 meter dan luas tajuk \pm $1 \mathrm{~m}^{2}$. Kedua, pengambilan sampel tanah. Pengambilan sampel tanah dari rhizosfer gulma Siam yang ter-sampling, dilakukan di 10 titik yang ditentukan secara reguler di setiap lokasi pengambilan sampel. Dilakukan pengambilan sampel tanah secara monolit pada areal di sekitar gulma Siam dengan luas 20 x $20 \mathrm{~cm}$, dengan gulma Siam sebagai titik pusatnya, dan kedalaman \pm 20 cm untuk sampel nematoda. Untuk sampling VAM, sampel tanah diambil dari titik diagonal sebanyak lima titik pada daerah rizosfer gulma Siam pada kedalaman \pm 0-20 cm (lapisan humus) diambil sebanyak \pm 100 gram pada areal perakaran, sedangkan untuk sampling collembola dengan membuat plot berukuran 30 x $30 \mathrm{~cm}$ dengan gulma Siam sebagai titik pusatnya dan kedalaman \pm 20 $\mathrm{cm}$. Sampel tanah yang diambil kemudian dimasukkan ke dalam kantong plastik dan diberi label (Kesaulya et al., 2015). Ketiga, isolasi spora VAM. Isolasi spora VAM dilakukan dengan metode penyaringan dan penuangan basah (Brundrett et al., 1996). Pengamatan mikroskopis jaringan akar gulma Siam yang telah diwarnai dilakukan di bawah mikroskop untuk melihat adanya infeksi VAM.

Jumlah genus VAM yang ditemukan di tiga lahan berbeda dan persentase akar terinfeksi dianalisis secara deskriptif. Selain itu, hubungan antara faktor fisika dan kimia tanah dengan genus VAM di sekitar rizosfer gulma Siam juga dianalisis secara deskriptif. 
Collembola dihitung berdasarkan jumlah masing-masing spesies, dan indeks keanekaragaman didasarkan pada rumus Shannon-Wiener (Fachrul, 2008) untuk menentukan tingkat keragamannya di setiap lahan. Perbedaan kelimpahan dan keanekaragaman antarlahan dianalisis secara deskriptif. Demikian pula, hubungan antara faktor edafik dan struktur komunitas nematoda, VAM, dan collembola juga dilakukan secara deskriptif. Analisis signifikansi perbedaan persentase infeksi VAM pada akar rhizosfer gulma Siam di ketiga bentuk lahan dilakukan dengan uji Anova.

\section{HASIL DAN PEMBAHASAN}

Kondisi edafik ekosistem rhizosfer gulma Siam dari tiga bentuk lahan disajikan pada Tabel 1.

Kondisi edafik merupakan faktor penting yang mempengaruhi keberadaan VAM, collembola, dan nematoda. Sebagai contoh, kandungan hara yang rendah menyebabkan persentase infeksi VAM yang tinggi pada akar. Hal ini erat kaitannya dengan peran VAM dalam transfer hara. Infeksi VAM pada tanaman membantu meningkatkan penyerapan unsur hara terutama unsur $\mathrm{P}$, sehingga $\mathrm{P}$ tersedia bagi tanaman. Berkenaan dengan hal tersebut dapat dikatakan bahwa semakin rendah unsur P maka infeksi VAM pada tanaman semakin tinggi. Namun pada kondisi P mencukupi, akar tanaman dapat berperan sebagai organ penyerap hara sehingga tanaman mengakumulasi P dalam jumlah yang tinggi. $P$ yang tinggi menghambat VAM secara langsung dengan menekan perkecambahan spora dan pertumbuhan hifa dari spora yang berkecambah (Masria, 2008). Oleh karena itu, lahan karst yang memiliki kandungan $\mathrm{P}_{2} \mathrm{O}_{5}$ lebih rendah dibandingkan lahan lainnya (Tabel 1), memiliki tingkat infeksi VAM tertinggi (Tabel 2). Berdasarkan uji

Tabel 1

Sifat Fisik dan Kimia Sampel Tanah di Ketiga Lahan

\begin{tabular}{lccc}
\hline \multirow{2}{*}{\multicolumn{1}{c}{ Parameter }} & \multicolumn{3}{c}{ Bentuk Lahan } \\
\cline { 2 - 4 } & Karst & Pesisir & Vulkanik \\
\hline Total-N $(\%)$ & 0.11 & 0.05 & 0.08 \\
Potential $\mathrm{P}_{2} \mathrm{O}_{5}(\mathrm{mg} / 100 \mathrm{~g})$ & 81 & 220 & 211 \\
Potential $\mathrm{K}_{2} \mathrm{O}(\mathrm{mg} / 100 \mathrm{~g})$ & 15 & 6 & 12 \\
Organic-C $(\%)$ & 0.82 & 0.53 & 0.67 \\
Soil $\mathrm{pH}$ & 5.5 & 6.88 & 6.64 \\
Soil humidity (\%) & 100 & 15.8 & 36 \\
Soil temperature & 28.8 & 30 & 24.8 \\
Soil texture & Clay soil & Sandy soil & Clay-sand soil \\
\hline
\end{tabular}


Keanekaragaman Organisme (Aminatun, T. dkk.)

Tabel 2

Persentase Infeksi VAM pada Akar Gulma Siam

\begin{tabular}{|c|c|c|c|c|c|c|c|}
\hline \multirow[t]{2}{*}{ Bentuk Lahan } & \multicolumn{5}{|c|}{$\begin{array}{l}\text { Persentase Infeksi VAM pada Akar Gulma } \\
\text { Siam Ulangan (\%) }\end{array}$} & \multirow{2}{*}{$\begin{array}{c}\text { Rerata } \\
(\%)\end{array}$} & \multirow[t]{2}{*}{ Kelas Infeks } \\
\hline & 1 & 2 & 3 & 4 & 5 & & \\
\hline Karst & 100 & 96 & 96 & 100 & 100 & 98,4 & Sangat tinggi \\
\hline Pesisir & 84 & 88 & 92 & 80 & 80 & 84,8 & Sangat tinggi \\
\hline Vulkanik & 32 & 40 & 96 & 56 & 84 & 61,6 & Tinggi \\
\hline
\end{tabular}

beda dengan Anova diperoleh hasil bahwa angka sig. 0,012 (lebih kecil dari 0,05) sehingga perbedaan persentase infeksi VAM pada akar gulma Siam antara lahan karst, pesisir, dan vulkanik tersebut adalah signifikan. Identifikasi spora VAM yang berhasil diisolasi dari rhizosfer gulma Siam disajikan pada Tabel 3.

Perbedaan sifat fisik dan kimia tanah dari ketiga jenis lahan menyebabkan

Tabel 3

Hasil Isolasi dan Identifikasi VAM yang Diperoleh dari Rhizosfer Gulma Siam di Tiga Lahan Berbeda

\begin{tabular}{|c|c|c|c|c|c|}
\hline No & $\begin{array}{c}\text { Tipe Spora } \\
\text { Glomus dg } \\
\text { Perbesaran 100x }\end{array}$ & Deskripsi & No & $\begin{array}{c}\text { Tipe Spora } \\
\text { Gigaspora dg } \\
\text { Perbesaran 100x }\end{array}$ & Deskripsi \\
\hline 1 & & $\begin{array}{l}\text { Glomus sp.1, globe- } \\
\text { shaped, black, } 95.5 \mu \mathrm{m} ;\end{array}$ & 1 & & $\begin{array}{l}\text { Gigaspora sp.1, globe- } \\
\text { shaped, gray, } 240.8 \mu \mathrm{m}\end{array}$ \\
\hline 2 & & $\begin{array}{l}\text { Glomus sp. } 2 \text {, globe- } \\
\text { shaped, gray, } 71.1 \mu \mathrm{m}\end{array}$ & 2 & & $\begin{array}{l}\text { Gigaspora sp.2, globe- } \\
\text { shaped, black, } 279.5 \mu \mathrm{m}\end{array}$ \\
\hline 3 & & $\begin{array}{l}\text { Glomus sp. } 3 \text {, globe- } \\
\text { shaped, blackish- } \\
\text { orange, } 87.4 \mu \mathrm{m} \text {; }\end{array}$ & 3 & & $\begin{array}{l}\text { Gigaspora sp.3, globe- } \\
\text { shaped, yellow, } 265.7 \\
\mu \mathrm{m} \text {; Bulbous suspensor } \\
\text { (pointed) }\end{array}$ \\
\hline 4 & & $\begin{array}{l}\text { Glomus sp.4, globe- } \\
\text { shaped, black, } 74.9 \mu \mathrm{m} . \\
\text { Subtending hyphae } \\
\text { (pointed) }\end{array}$ & 4 & & $\begin{array}{l}\text { Gigaspora sp.4, globe- } \\
\text { shaped, blackish-orange, } \\
198.7 \mu \mathrm{m}\end{array}$ \\
\hline 5 & & $\begin{array}{l}\text { Glomus sp.5, globe- } \\
\text { shaped, yellowish, } 84.1 \\
\mu \mathrm{m}\end{array}$ & 5 & & $\begin{array}{l}\text { Gigaspora sp.5, globe- } \\
\text { shaped, brownish-orange, } \\
305.3 \mu \mathrm{m}\end{array}$ \\
\hline 6 & & $\begin{array}{l}\text { Glomus sp.6, globe- } \\
\text { shaped, hyalin-colored, } \\
45.3 \mu \mathrm{m}\end{array}$ & & & \\
\hline 7 & & $\begin{array}{l}\text { Glomus sp. } 7 \text {, globe- } \\
\text { shaped, brownish-black, } \\
95.3 \mu \mathrm{m}\end{array}$ & & & \\
\hline
\end{tabular}


perbedaan komposisi genus VAM yang ditemukan. Ditemukan enam spesies VAM di lahan karst yang mempunyai tekstur tanah liat, empat spesies berasal dari genus Glomus dan dua spesies adalah Gigaspora. Lahan pesisir memiliki 10 spesies VAM, lima di antaranya adalah Glomus dan sisanya adalah Gigaspora. Pada lahan vulkanik yang bertekstur tanah lempung berpasir ditemukan 10 jenis VAM, enam di antaranya adalah Glomus dan empat di antaranya adalah genus Gigaspora. Hal ini kemungkinan disebabkan oleh kecilnya pori-pori tanah pada kawasan karst yang berdampak pada berkurangnya spora VAM. Gigaspora banyak ditemukan di pantai berpasir karena pasir memiliki pori-pori yang lebih besar dari jenis tanah lainnya sehingga cocok untuk pertumbuhan Gigaspora yang ukurannya relatif besar (Suamba et al., 2014).

Tekstur tanah berkaitan dengan ukuran partikel dan pori tanah. Tekstur tanah yang semakin kasar menyebabkan poripori tanah semakin membesar sehingga semakin banyak lapisan udara yang terikat dalam butiran tanah. Ini merupakan bukti bahwa cekaman hidrologi merupakan faktor pembatas bagi keanekaragaman komunitas bakteri dari organisme tanah lainnya. Keanekaragaman bakteri dan organisme tanah akan mempengaruhi proses penguraian bahan organik dalam tanah, sedangkan aktivitas biokimia komunitas organisme tanah akan mempengaruhi $\mathrm{pH}$ tanah (Chau et al., 2011).

Penelitian pada tanah lempung berlumpur dengan kisaran $\mathrm{pH}$ 8,3 sampai 4,0; penurunan $\mathrm{pH}$; penurunan pertumbuhan bakteri lima kali lipat tetapi pertumbuhan jamur meningkat lima kali lipat; dan penurunan mineralisasi karbon total; sedangkan $\mathrm{pH}<4,5$ kerja mikroba terhambat akibat pelepasan aluminium bebas dan penurunan produktivitas tanaman (Rousk et al., 2009). Pengaruh $\mathrm{pH}$ tanah terhadap organisme tanah sangat dipengaruhi oleh perbedaan jenis tanah, tutupan vegetasi dan kondisi iklim setempat. Berdasarkan Tabel 1, kawasan karst memiliki pH yang lebih rendah dibandingkan kawasan vulkanik dan pesisir. Hal tersebut tidak akan berdampak negatif pada kelimpahan nematoda, karena menurut (Ravinndra et al., 2017) nematoda memiliki rentang toleransi $\mathrm{pH}$ yang cukup besar; bahkan banyak spesies yang dapat bertahan hidup pada $\mathrm{pH} 3,5$. Larva nematoda bahkan tahan terhadap kondisi kering.

Hasil pengamatan (Tabel 4) menunjukkan bahwa terdapat 55 marga dari 33 famili nematoda. Struktur komunitas nematoda di kawasan karst jelas didominasi oleh genus tertentu yang dapat dilihat dari hasil perhitungan Indeks Diversitasnya (Gambar 2). Indeks Diversitas (H') dari ketiga lokasi menunjukkan tingkat keanekaragaman nematoda sedang $\left(1,5 \leq \mathrm{H}^{\prime} \leq 3,5\right)$. Namun 
Indeks Keanekaragaman di kawasan karst $\left(H^{\prime}=1,82\right)$ lebih rendah dibandingkan di pesisir $\left(H^{\prime}=2,91\right)$ dan di kawasan vulkanik $\left(\mathrm{H}^{`}=3,06\right)$.
Tekstur tanah menentukan distribusi pori dan kelembaban. Nematoda bergerak di antara pori-pori dengan diameter 20-30 $\mu \mathrm{m}$ atau lebih besar. Tekstur tanah menunjukkan

Tabel 4

Kemelimpahan Relatif (KR)Nematoda yang Diisolasi dari Sampel Tanah Rhizosfer Gulma Siam

\begin{tabular}{|c|c|c|c|c|c|c|c|c|}
\hline \multirow[b]{2}{*}{ No } & \multirow[b]{2}{*}{ Familia } & \multirow[b]{2}{*}{ Genus } & \multicolumn{2}{|c|}{ Karst } & \multicolumn{2}{|c|}{ Pesisir } & \multicolumn{2}{|c|}{ Vulkanik } \\
\hline & & & $\begin{array}{c}\sum \text { rerata } \\
\text { (individu/ } \\
\text { 100cc tanah) }\end{array}$ & $\begin{array}{l}\text { KR } \\
(\%)\end{array}$ & $\begin{array}{c}\sum \text { rerata } \\
\text { (individu/ } \\
100 \mathrm{cc} \text { tanah) }\end{array}$ & $\begin{array}{l}\text { KR } \\
(\%)\end{array}$ & $\begin{array}{c}\sum \text { rerata } \\
\text { (individu/ } \\
100 \mathrm{cc} \text { tanah) }\end{array}$ & $\begin{array}{l}\text { KR } \\
(\%)\end{array}$ \\
\hline 1 & Alaimidae & Alaimus & 1,2 & 0,77 & 0 & 0,00 & 0,6 & 0,29 \\
\hline \multirow[t]{3}{*}{2} & Anguinidae & Ditylenchus & 0 & 0,00 & 1,2 & 0,85 & 0 & 0,00 \\
\hline & & Nothotylenchus sp1 & 11 & 7,06 & 27,6 & 19,60 & 15,2 & 7,31 \\
\hline & & Nothotylenchus sp2 & 0 & 0,00 & 3 & 2,13 & 0,6 & 0,29 \\
\hline 3 & Aphelenchoididae & Aphelen 1 & 0,2 & 0,13 & 1,2 & 0,85 & 1,4 & 0,67 \\
\hline \multirow[t]{6}{*}{4} & Cephalobidae & Acrobeles & 0 & 0,00 & 0,4 & 0,28 & 0 & 0,00 \\
\hline & & Cephalobus & 0,2 & 0,13 & 0 & 0,00 & 0,2 & 0,10 \\
\hline & & Chiloplacus & 0 & 0,00 & 6,6 & 4,69 & 3,6 & 173 \\
\hline & & Eucephalobus & 0 & 0,00 & 1,2 & 0,85 & 3,2 & 1,54 \\
\hline & & Cepha 1 & 0 & 0,00 & 0 & 0,00 & 0,4 & 019 \\
\hline & & Cepha 2 & 1,2 & 0,77 & 9 & 6,39 & 3,8 & 1,83 \\
\hline 5 & Criconematidae & Mesocriconema & 0 & 0,00 & 0 & 0,00 & 6 & 2,88 \\
\hline 6 & Diplogasteridae & Pristionchus & 0 & 0,00 & 0 & 0,00 & 0,6 & 0,29 \\
\hline \multirow[t]{4}{*}{7} & Dorylaimidae & Eudorylaimus & 0 & 0,00 & 0,4 & 0,28 & 0,2 & 0,10 \\
\hline & & Labronema & 12,4 & 7,96 & 0,8 & 0,57 & 8,4 & 4,04 \\
\hline & & Mesodorylaimus & 0 & 0,00 & 0,6 & 0,43 & 1,8 & 0,87 \\
\hline & & Prodorylaimus & 14,8 & 9,50 & 3,8 & 2,70 & 14 & 6,73 \\
\hline \multirow[t]{3}{*}{8} & Hoplolaimidae & Helicotylenchus sp1 & 11 & 7,06 & 0 & 0,00 & 1,4 & 0,67 \\
\hline & & Helicotylenchus sp2 & 0,2 & 0,13 & 0,2 & 0,14 & 0,6 & 0,29 \\
\hline & & Hoplolaimus & 0 & 0,00 & 4,6 & 3,27 & 1 & 0,48 \\
\hline 9 & Longidoridae & Longi 1 & 2,4 & 1,54 & 0,4 & 0,28 & 2 & 0,96 \\
\hline 10 & Mononchidae & Mylonchulus & 4,8 & 3,08 & 0 & 0,00 & 10,8 & 5,19 \\
\hline \multirow[t]{5}{*}{11} & Nygolaimidae & Nygolaimus sp1 & 2,4 & 1,54 & 3,8 & 2,70 & 15,8 & 7,60 \\
\hline & & Nygolaimus sp2 & 2 & 1,28 & 0 & 0,00 & 0,4 & 0,19 \\
\hline & & Nygolaimus sp3 & 1,2 & 0,77 & 0 & 0,00 & 0 & 0,00 \\
\hline & & Nygolaimus sp4 & 0 & 0,00 & 0 & 0,00 & 23,4 & 11,25 \\
\hline & & Nygolaimus sp5 & 0 & 0,00 & 0,2 & 0,14 & 0 & 0,00 \\
\hline 12 & Plectidae & Wilsonema & 0 & 0,00 & 4 & 2,84 & 0 & 0,00 \\
\hline \multirow[t]{2}{*}{13} & Panagrolaimidae & Panagrolaimus sp1 & 0,8 & 0,51 & 14,2 & 10,09 & 9,4 & 4,52 \\
\hline & & Panagrolaimus sp2 & 0 & 0,00 & 0,4 & 0,28 & 1,6 & 0,77 \\
\hline \multirow[t]{2}{*}{14} & Pratylenchidae & Pratylenchus sp1 & 3,6 & 2,31 & 0 & 0,00 & 2,8 & 1,35 \\
\hline & & Pratylenchus sp2 & 82,4 & 52,89 & 2,2 & 1,56 & 15,6 & 7,50 \\
\hline 15 & Prismatolaimidae & Prisma 1 & 0,6 & 0,39 & 0,6 & 0,43 & 0 & 0,00 \\
\hline
\end{tabular}


Lanjutan Tabel 4

Kemelimpahan Relatif (KR)Nematoda yang Diisolasi dari Sampel Tanah Rhizosfer Gulma Siam

\begin{tabular}{|c|c|c|c|c|c|c|c|c|}
\hline \multirow[b]{2}{*}{ No } & \multirow[b]{2}{*}{ Familia } & \multirow[b]{2}{*}{ Genus } & \multicolumn{2}{|c|}{ Karst } & \multicolumn{2}{|l|}{ Pesisir } & \multicolumn{2}{|c|}{ Vulkanik } \\
\hline & & & $\begin{array}{c}\sum \text { rerata } \\
\text { (individu/ } \\
\text { 100cc tanah) }\end{array}$ & $\begin{array}{l}\text { KR } \\
(\%)\end{array}$ & $\begin{array}{c}\sum \text { rerata } \\
\text { (individu/ } \\
100 \mathrm{cc} \text { tanah) }\end{array}$ & $\begin{array}{l}\text { KR } \\
(\%)\end{array}$ & $\begin{array}{c}\sum \text { rerata } \\
\text { (individu/ } \\
100 \mathrm{cc} \text { tanah) }\end{array}$ & $\begin{array}{l}\text { KR } \\
(\%)\end{array}$ \\
\hline \multirow[t]{2}{*}{16} & Rhabditidae & Rhabditis sp1 & 0 & 0,00 & 0,4 & 0,28 & 0 & 0,00 \\
\hline & & Rhabditis sp2 & 0 & 0,00 & 0,4 & 0,28 & 0 & 0,00 \\
\hline \multirow[t]{3}{*}{17} & Rhabdolaimidae & Monochromadora sp1 & 0 & 0,00 & 0,6 & 0,43 & 6,6 & 3,17 \\
\hline & & Monochromadora sp2 & 0,4 & 0,26 & 1 & 0,71 & 0 & 0,00 \\
\hline & & Rhabdolaimus & 0 & 0,00 & 10,2 & 7,24 & 24,2 & 11,63 \\
\hline 18 & Seinuridae & Seinura & 0 & 0,00 & 0,2 & 0,14 & 0,4 & 0,19 \\
\hline \multirow[t]{2}{*}{19} & Tylenchidae & Tylencholaimus & 0 & 0,00 & 8,4 & 5,97 & 0 & 0,00 \\
\hline & & Tylen 1 & 0 & 0,00 & 1,4 & 0,99 & 0,6 & 0,29 \\
\hline 20 & Tylenchorhynchidae & Tylenchorhynchus & 1,2 & 0,77 & 0 & 0,00 & 10,8 & 5,19 \\
\hline 21 & Nematode & $\mathrm{N} 1$ & 0,2 & 0,13 & 0,4 & 0,28 & 0,4 & 0,19 \\
\hline 22 & Nematode & $\mathrm{N} 2$ & 0,2 & 0,13 & 0 & 0,00 & 3,2 & 1,54 \\
\hline 23 & Nematode & $\mathrm{N} 3$ & 0,8 & 0,51 & 4,8 & 3,41 & 0,2 & 0,10 \\
\hline 24 & Nematode & N4 & 0,2 & 0,13 & 0 & 0,00 & 0,6 & 0,29 \\
\hline 25 & Nematode & N5 & 0,2 & 0,13 & 0 & 0,00 & 0,4 & 0,19 \\
\hline 26 & Nematode & N6 & 0,2 & 0,13 & 0,4 & 0,28 & 0,2 & 0,10 \\
\hline 27 & Nematode & N7 & 0 & 0,00 & 0 & 0,00 & 1,6 & 0,77 \\
\hline 28 & Nematode & N8 & 0 & 0,00 & 0 & 0,00 & 0 & 0,00 \\
\hline 29 & Nematode & N9 & 0 & 0,00 & 4 & 2,84 & 8 & 3,85 \\
\hline 30 & Nematode & N10 & 0 & 0,00 & 13,8 & 9,80 & 0 & 0,00 \\
\hline 31 & Nematode & N11 & 0 & 0,00 & 0,6 & 0,43 & 0 & 0,00 \\
\hline 32 & Nematode & N12 & 0 & 0,00 & 5 & 3,55 & 0,8 & 0,38 \\
\hline \multirow[t]{2}{*}{33} & Nematode & N13 & 0 & 0,00 & 2,8 & 1,99 & 5,2 & 2,50 \\
\hline & & tal & 155.8 & 100.00 & 140,8 & 100,00 & 208 & 100,00 \\
\hline
\end{tabular}

Keterangan: Nematoda (N): Nematoda yang tidak teridentifikasi berdasarkan karakter morfofologi

Gambar 2

Grafik Indeks Diversitas ( $H^{\prime}$ ) dan Indeks Kemerataan (E) dari Komunitas Nematoda

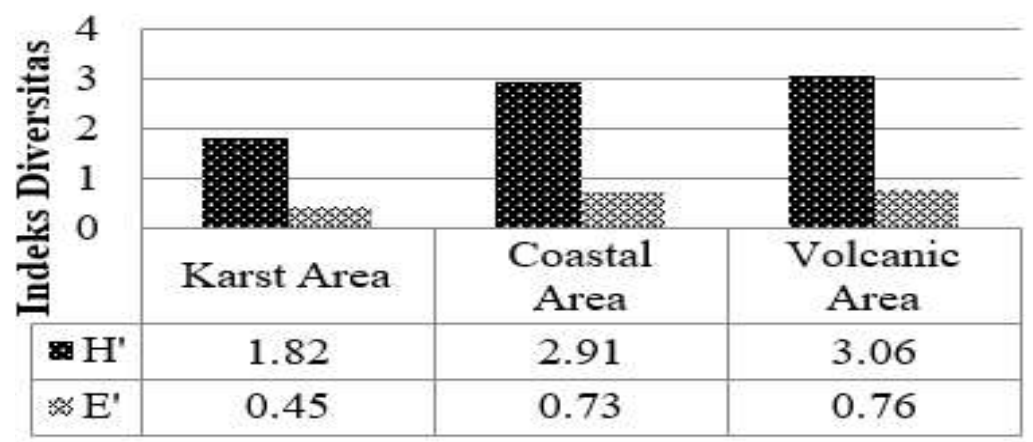


bahwa lahan karst mengandung 34\% pasir, $18 \%$ debu dan $48 \%$ lempung. Lahan pesisir mengandung $98 \%$ pasir, $1 \%$ debu dan $1 \%$ tanah liat, sedangkan lahan vulkanik mengandung $78 \%$ pasir, $14 \%$ debu, dan $8 \%$ tanah liat (Tabel 1). Dropkin (1992) menjelaskan bahwa partikel dengan diameter kurang lebih $2 \mu \mathrm{m}$ dapat membentuk lempung. Debu tersusun dari partikel dengan diameter 2-50 $\mu \mathrm{m}$ sedangkan pasir mengandung partikel dengan diameter berkisar antara 50 hingga $2000 \mu \mathrm{m}$. Perbedaan komposisi tanah akan berpengaruh pada ketersediaan pori. Meskipun nematoda hanya bergerak beberapa sentimeter dari satu tempat ke tempat lain, mereka dapat tetap hidup selama mereka dapat bergerak di tanah dan air. Hal ini memungkinkan terjadinya perbedaan keanekaragaman karena pori-pori tanah memberikan akses mobilitas bagi nematoda. Tekstur tanah juga berkaitan erat dengan sebaran ukuran pori tanah dan perilaku air tanah.

Berdasarkan hasil analisis, perbedaan indeks keanekaragaman nematoda pada ketiga jenis tanah tersebut dipengaruhi oleh tekstur tanah. Ketika nematoda mampu bergerak lebih leluasa, kemungkinan mendapatkan makanan untuk bertahan hidup juga semakin tinggi. Selain itu, pori-pori tanah juga memudahkan pergerakan air, dan nematoda mudah didistribusikan oleh aliran air.

Faktor lingkungan juga menentukan struktur komunitas Collembola. Keaneka- ragaman Collembola menunjukkan tingkat toleransi terhadap lingkungan (Husamah et al. 2016). Tingginya keanekaragaman Collembola di lahan pesisir (Tabel 5) diduga karena adanya vegetasi yang banyak menghasilkan sampah organik. Leinaas et al. (2015) menjelaskan bahwa keaktifan Collembola sangat ditentukan oleh banyaknya vegetasi yang banyak menghasilkan sampah organik karena merupakan sumber nutrisi bagi Collembola. Hal ini terkait dengan peran Collembola sebagai pengurai sampah organik.

Lahan karst mempunyai kandungan $\mathrm{N}$ dan $\mathrm{C}$ organik tertinggi (Tabel 1). Kandungan $\mathrm{N}$ dan $\mathrm{C}$ organik tanah sangat mempengaruhi keberadaan Collembola, karena berperan aktif dalam mengontrol rasio $\mathrm{C} / \mathrm{N}$ di dalam tanah. Hal ini sejalan dengan penelitian Liu et al. (2019) yang menemukan bahwa Collembola merupakan organisme tanah dominan yang berperan dalam pelepasan karbon dari proses dekomposisi serasah, yang perannya semakin berkurang dengan bertambahnya ketinggian. Tingginya keragaman organisme tanah akan mempercepat dekomposisi serasah.

Pada penelitian ini nilai $\mathrm{C} / \mathrm{N}$ di lahan vulkanik, pesisir, dan karst masing-masing adalah 8,$37 ; 10,6$; dan 7,45. Nilai indeks diversitas Collembola tertinggi terdapat di wilayah pesisir, diikuti oleh wilayah vulkanik dan karst. Dengan demikian, 
Tabel 5

Komposisi Genus Collembola yang Diisolasi dari Rhizosfer Gulma Siam di Ketiga Bentuk Lahan

\begin{tabular}{|c|c|c|c|c|c|c|}
\hline \multirow[b]{2}{*}{ No } & \multirow[b]{2}{*}{ Ordo } & \multirow[b]{2}{*}{ Familia } & \multirow[b]{2}{*}{ Genus } & \multicolumn{3}{|c|}{ Kemelimpahan (Individu) } \\
\hline & & & & $\begin{array}{c}\text { Lahan } \\
\text { Vulkanik }\end{array}$ & $\begin{array}{l}\text { Lahan } \\
\text { Pesisir }\end{array}$ & $\begin{array}{c}\text { Lahan } \\
\text { Karst }\end{array}$ \\
\hline 1 & Poduromorpha & Hypogastruridae & Xenylla & 0 & 24 & 0 \\
\hline 2 & & Neanuridae & Anura & 0 & 2 & 0 \\
\hline 3 & & & Pseudachorutes & 0 & 1 & 0 \\
\hline 4 & & & Gnatholonche & 0 & 0 & 1 \\
\hline 5 & & & Blaseonura & 5 & 0 & 0 \\
\hline 6 & Entomobry-omorpha & Isotomidae & Isotomiella & 5 & 0 & 0 \\
\hline 7 & & Entomobryidae & Acrocyrtus & 2 & 4 & 4 \\
\hline 8 & & & Lepidocyrtus & 3 & 10 & 12 \\
\hline 9 & & & Pseudosinella & 0 & 2 & 0 \\
\hline 10 & & & Entomobrya & 0 & 16 & 0 \\
\hline 11 & & Paronellidae & Callyntrura & 0 & 35 & 9 \\
\hline 12 & & & Salina & 12 & 62 & 6 \\
\hline 13 & & & Cyphoderopsis & 0 & 10 & 0 \\
\hline \multirow[t]{3}{*}{14} & Symphypleona & Sminthuridae & Sphyrotheca & 0 & 1 & 0 \\
\hline & Total & & & 27 & 167 & 32 \\
\hline & Indeks Diversitas (H & & & 1,42 & 1,79 & 1,41 \\
\hline
\end{tabular}

kawasan dengan rasio $\mathrm{C} / \mathrm{N}$ tertinggi juga memiliki indeks diversitas tertinggi atau Collembola paling beragam.

$\mathrm{Ke}$ et al. (2004) mengungkapkan bahwa $\mathrm{pH}$ yang rendah mempengaruhi perkembangan, reproduksi, pertumbuhan, dan kelangsungan hidup Collembola. Tanah asam bisa berbahaya bagi komunitas Collembola. Artinya, rendahnya keragaman collembola di kawasan karst dipengaruhi oleh tingkat keasaman $\mathrm{pH}$ kawasan tersebut. Seperti disajikan pada Tabel 1, daerah pesisir cenderung memiliki tingkat $\mathrm{pH}$ netral, sedangkan daerah karst lebih asam $(5,56)$. Hal ini menunjukkan bahwa eksudat yang dihasilkan oleh gulma Siam pada lingkungan yang berbeda mempengaruhi tingkat $\mathrm{pH}$ lingkungan (rhizosfer). Eksudat menarik Collembola untuk mendapatkan nutrisi, sedangkan Collembola mendegradasi bahan organik dan memberikan nutrisi dalam tanah. Kondisi asam juga dipengaruhi oleh nitrogen. akar melepaskan asamasam organik yang akan menjadi sumber makanan bagi mikroorganisme dan organisme tanah yang lain. Rhizosfer merupakan area mikroorganisme tanah terpenting yang menentukan dinamika dan siklus karbon serta nutrient lain dan air di ekosistem tanah, yang dapat dilihat 
dari parameter kandungan $\mathrm{C}$, nutrient, $\mathrm{pH}$, aktivitas enzim, dan mikroorganisme tanah. Proses ini memungkinkan rhizosfer menjadi lingkungan paling dinamis di dalam tanah (Adeleke et al., 2017).

\section{SIMPULAN}

Hasil penelitian menunjukkan bahwa tanah pada rhizosfer gulma Siam yang tumbuh di lahan karst menunjukkan tingkat kesuburan tertinggi yang ditunjukkan oleh kandungan N, K, dan C-organik tanah, sedangkan tanah pesisir memiliki kandungan $\mathrm{P}$ tertinggi. Tekstur tanah pada rizosfer gulma Siam lebih berpengaruh terhadap keanekaragaman organisme tanah dibandingkan kandungan hara tanah dan sifat tanah lainnya yang diteliti. Keragaman organisme tanah rizosfer gulma Siam lebih besar di daerah pesisir dibandingkan di lahan karst dan vulkanik. Implikasi dari hasil tersebut adalah bahwa tanah dengan tekstur berpasir akan lebih bermanfaat bagi pertumbuhan gulma Siam dengan keanekaragaman organisme rhizosfer yang lebih tinggi.

\section{DAFTAR PUSTAKA}

Adeleke, R., Nwangburuka, C., \& Oboirien, B. (2017). Origins, roles and fate of organic acids in soils: A review. South African Journal of Botany, 108, 393-406. https:// doi.org/10.1016/j.sajb.2016.09.002.

Brundrett, M., Bougher, N., Dell, B., Grove, T., \& Malajczuk, N. (1996). Working with mycorrhizas in forestry and agriculture. Dalam Australian Centre for International Agricultural Research, 32. Diunduh dari https://www.aciar.gov. au/publication/working-mycorrhizasforestry-and-agriculture.

Buendia, L., Wang, T., Girardin, A., \& Lefebvre, B. (2016). The LysM receptor-like kinase SILYK10 regulates the arbuscular mycorrhizal symbiosis in tomato. New Phytologist, 210(1), 184195. https://doi.org/10.1111/nph.13753. Castoldi, G., dos Reis, J. G., Pivetta, L. A., \& Rosolem, C. A. (2013). Dinămica do nitrogěnio no solo após a dessecação de brachiarias. Revista Brasileira de Ciencia Do Solo, 37(6), 16201627. https://doi.org/10.1590/S010006832013000600018.

Chau, J. F., Bagtzoglou, A. C., \& Willig, M. R. (2011). The effect of SOil texture on richness and diversity of bacterial communities. Environmental Forensics, 12, 333-341. https://doi.org/10.1080/15 275922.2011.622348.

Dropkin, V. H. (1992). Pengantar nematologi tumbuhan. (Supratoyo, Terj.). Mada University Press.

Fachrul, M. F. (2008). Metode sampling bioteknologi. Bumi Aksara.

Flores-Gallegos, A. C., \& Nava-Reyna, E. (2018). Plant growth-promoting microbial enzymes. Enzymes in food biotechnology: Production, applications, and future prospects. https:// doi.org/10.1016/B978-0-12-8132807.00030-X.

Gebremikael, M. T., Steel, H., Bert, W., Maenhout, P., Sleutel, S., \& De Neve, S. (2015). Quantifying the contribution of entire free-living nematode communities to carbon mineralization under contrasting $\mathrm{C}$ and $\mathrm{N}$ availability. PLoS ONE, 10(9), 1-17. https://doi. org/10.1371/journal.pone.0136244

Graf, M., Bönn, M., Feldhahn, L., Kurth, F., Grams, T. E. E., Herrmann, S., 
Tarkka, M., Buscot, F., \& Scheu, S. (2019). Collembola interact with mycorrhizal fungi in modifying oak morphology, $\mathrm{C}$ and $\mathrm{N}$ incorporation and transcriptomics. Royal Society Open Science, 6(3). https://doi.org/10.1098/ rsos.181869.

Gregory, P. J. (2006). Roots, rhizosphere and soil: The route to a better understanding of soil science? Europian Journal of Soil Science, February(57), 2-12. https://doi.org/10.1111/j.13652389.2005.00778.x.

Guerra, C. A., Heintz-Buschart, A., Sikorski, J., Chatzinotas, A., Guerrero-Ramírez, N., Cesarz, S., Beaumelle, L., Rillig, M. C., Maestre, F. T., Delgado-Baquerizo, M., Buscot, F., Overmann, J., Patoine, G., Phillips, H. R. P., Winter, M., Wubet, T., Küsel, K., Bardgett, R. D., Cameron, E. K., ... Eisenhauer, N. (2020). Blind spots in global soil biodiversity and ecosystem function research. Nature Communications, 11(1), 1-13. https:// doi.org/10.1038/s41467-020-17688-2.

Husamah, H., Rohman, F., \& Sutomo, H. (2016). Struktur komunitas collembola pada tiga tipe habitat sepanjang daerah aliran sungai Brantas Hulu Kota Batu. Bioedukasi, 9(1), 45-50. https:// doi.org/10.20961/bioedukasi-uns. v9i1.3886.

Husna, Budi, S. W., Mansur, I., \& Kusmana, D. C. (2015). Diversity of arbuscular mycorrhizal fungi in the growth habitat of Kayu Kuku (Pericopsis mooniana Thw.) in Southeast Sulawesi. Pakistan Journal of Biological Sciences, 18(1), 1-10. https://doi.org/10.3923/ pjbs.2015.1.10.

Illig, J., Norton, R. A., Scheu, S., \& Maraun, M. (2010). Density and community structure of soil- and bark-dwelling microarthropods along an altitudinal gradient in a tropical montane rainforest.
Experimental and Applied Acarology, 52(1), 49-62. https://doi.org/10.1007/ s10493-010-9348-x.

Irshad, U., \& Yergeau, E. (2018). Bacterial subspecies variation and nematode grazing change $P$ dynamics in the wheat rhizosphere. Frontiers in Microbiology, 9(SEP), 1-11. https://doi.org/10.3389/ fmicb.2018.01990.

Kanfra, X., Liu, B., Beerhues, L., Sørensen, S. J., \& Heuer, H. (2018). Free-living nematodes together with associated microbes play an essential role in apple replant disease. Frontiers in Plant Science, 9(November), 1-13. https:// doi.org/10.3389/fpls.2018.01666

Kartika, E., Duaja, M. D., \& Gusniwati. (2019). Diversity of Arbuscular Mycorrhizal Fungi from Liberica Tungkal Jambi Coffee plant rhizosphere on peatland. IOP Conference Series: Earth and Environmental Science, 391(1). https://doi.org/10.1088/17551315/391/1/012058

Ke, X., Yang, Y., Yin, W., \& Xue, L. (2004). Effects of low $\mathrm{pH}$ environment on the collembolan Onychiurus yaodai. Pedobiologia, 48, 545-550. https://doi. org/10.1016/j.pedobi.2004.07.001.

Kesaulya, H., Baharuddin, Zakaria, B., \& Syaiful, S. A. (2015). Isolation and Physiological Characterization of PGPR from Potato Plant Rhizosphere in Medium Land of Buru Island. Procedia Food Science, 3, 190-199. https://doi. org/10.1016/j.profoo.2015.01.021

Kolesnikova, A. A., Baturina, M. A., Shadrin, D. M., Konakova, T. N., \& Taskaeva, A. A. (2019). New records of lumbricidae and collembola in anthropogenic soils of east European tundra. ZooKeys, 2019(885), 15-25. https://doi. org/10.3897/zookeys.885.37279

Lehmann, A., Zheng, W., \& Rillig, M. C. (2017). Soil biota contributions to soil 
aggregation. Nat Ecol Evol., 1(12), 1828-1835. https://doi.org/10.1038/ s41559-017-0344-y.Soil.

Leinaas, H. P., Bengtsson, J., JanionScheepers, C., \& Chown, S. L. (2015). Indirect effects of habitat disturbance on invasion: Nutritious litter from a grazing resistant plant favors alien over native Collembola. Ecology and Evolution, 5(16), 3462-3471. https:// doi.org/10.1002/ece3.1483.

Liu, W., Zhang, J., Norris, S. L., \& Murray, P. J. (2016). Impact of grassland reseeding, herbicide spraying and ploughing on diversity and abundance of soil arthropods. Frontiers in Plant Science, 7(AUG2016), 1-9. https://doi. org/10.3389/fpls.2016.01200

Liu, Y., Wang, L., He, R., Chen, Y., Xu, Z., Tan, B., Zhang, L., Xiao, J., Zhu, P., Chen, L., Guo, L., \& Zhang, J. (2019). Higher soil fauna abundance accelerates litter carbon release across an alpine forest-tundra ecotone. Scientific Reports, 9(1), 1-12. https:// doi.org/10.1038/s41598-019-47072-0.

Mai, W. F., \& Lyon, H. H. (1975). Pictorial key to genera of plant-parasitic nematodes ( $4^{\text {th }}$ ed.). Cornell University Press.

Maillet, F., Poinsot, V., André, O., PuechPagés, V., Haouy, A., Gueunier, M., Cromer, L., Giraudet, D., Formey, D., Niebel, A., Martinez, E. A., Driguez, H., Bécard, G., \& Dénarié, J. (2011). Fungal lipochitooligosaccharide symbiotic signals in arbuscular mycorrhiza. Nature, 469(7328), 58-64. https://doi. org/10.1038/nature09622.

Marizal, S., Muzakir, \& Syariyah, A. (2017). The diversity of Arbuscular Mycorrhiza Fungus (AMF) indigenous in peanuts (Arachis Hypogea L) rhizosphere under different elevation. Journal of Tropical Soils, 21(2), 109-114. https://doi. org/10.5400/jts.2016.v21i2.109-114.
Masria. (2008). Peranan Mikoriza Vesikular Arbuskular (MVA) untuk meningkatkan resistensi tanaman terhadap cekaman kekeringan dan ketersediaan $\mathrm{P}$ pada lahan kering. Partner, 15(1), 4856. https://doi.org/http://dx.doi.org/ 10.35726/jp.v15i1.110.

Miyata, K., Kozaki, T., Kouzai, Y., Ozawa, K., Ishii, K., Asamizu, E., Okabe, Y., Umehara, Y., Miyamoto, A., Kobae, Y., Akiyaman, K., Kaku, H., Nishizawa, Y., Shibuya, N., \& Nakagawa, T. (2014). The bifunctional plant receptor, OsCERK1, regulates both chitin-triggered immunity and arbuscular mycorrhizal symbiosis in rice. Plant and Cell Physiology, 55(11), 1864-1872. https://doi.org/10.1093/pcp/ pcu129.

Mougi, A., \& Kondoh, M. (2012). Diversity of interaction types and ecological community stability. Science, 337(6092), 349-351. https://doi. org/10.1126/science. 1220529 .

Nuzzo, A., De Martino, A., Di Meo, V., \& Piccolo, A. (2018). Potential alteration of iron-humate complexes by plant root exudates and microbial siderophores. Chemical and Biological Technologies in Agriculture, 5(1). https://doi. org/10.1186/s40538-018-0132-1.

Rasmann, S., Ali, J. G., Helder, J., \& van der Putten, W. H. (2012). Ecology and evolution of soil nematode chemotaxis. Journal of Chemical Ecology, 38(6), 615-628. https://doi.org/10.1007/ s10886-012-0118-6.

Ravinndra,H., Sehgal,M., Narasimhamurthy, H. B., Jayalakshmi, K., \& Khan, H. I. (2017). Rice root-knot nematode (Meloidogyne graminicola) an emerging problem. Int J Curr Microbiol App Sci, 6(8), 3143-3171. https://doi. org/10.20546/ijcmas.2017.608.376.

Rousk, J., Brookes, P. C., \& Baath, E. (2009). Contrasting Soil $\mathrm{pH}$ Effects on Fungal 
and Bacterial Growth Suggest Functional Redundancy in Carbon Mineralization. Applied and Environmental Microbiology, 75(6), 1589-1596. https://doi. org/10.1128/AEM.02775-8

Sarkar, U., Choudhary, B. K., \& Sharma, B. K. (2014). Vascular Arbuscular Mycorrhizal ( VAM ) spore diversity and density across the soil of degraded forest and rubber plantation in Tripura, India. American-Eurasian J. Agric. \& Environ. Sci., 14(10), 10801088. https://doi.org/10.5829/idosi. aejaes.2014.14.10.12432.

Schratzberger, M., Holterman, M., Van Oevelen, D., \& Helder, J. (2019). A Worm's World: Ecological Flexibility Pays off for Free-Living Nematodes in Sediments and Soils. BioScience, 69(11), 867-876. https://doi.org/10.1093/biosci/ biz086.

Suamba, I. W., Wirawan, I. G. P., \& Adiartayasa, W. (2014). Isolasi dan identifikasi Fungi Mikoriza Arbuskular (FMA) secara mikroskopis pada rhizosfer tanaman jeruk (Citrus Sp.) di Desa Kerta, Kecamatan Payangan, Kabupaten Gianyar. E-Jurnal Agroekoteknologi Tropika (Journal of Tropical Agroecotechnology), 3(4), 201-208.

Sun, X., Zhang, X., Zhang, S., Dai, G., Han, S., \& Liang, W. (2013). Soil nematode responses to increases in nitrogen deposition and precipitation in a temperate forest. PLoS ONE, 8(12), 1-8. https://doi.org/10.1371/journal. pone. 0082468 .

te Beest, M., Elschot, K., Olff, H., \& Etienne, R. S. (2013). Invasion success in a marginal habitat: An experimental test of competitive ability and drought tolerance in chromolaena odorata. PLoS ONE, 8(8), e68274. https://doi. org/10.1371/journal.pone.0068274.
Treonis, A. M., Unangst, S. K., Kepler, R. M., Buyer, J. S., Cavigelli, M. A., Mirsky, S. B., \& Maul, J. E. (2018). Characterization of soil nematode communities in three cropping systems through morphological and DNA metabarcoding approaches. Scientific Reports, 8(1), 1-12. https://doi. org/10.1038/s41598-018-20366-5.

Van den Hoogen, J., Geisen, S., Wall, D. H., Wardle, D. A., Traunspurger, W., de Goede, R. G. M., Adams, B. J., Ahmad, W., Ferris, H., Bardgett, R. D., Bonkowski, M., Campos-Herrera, R., Cares, J. E., Caruso, T., Caixeta, L. D. B., Chen, X., Costa, S. R., Creamer, R., e Castro, J. M. D. C., ... Crowther, T. W. (2020). A global database of soil nematode abundance and functional group composition. Scientific Data, 7(1), 1-8. $\quad$ https://doi.org/10.1038/s41597020-0437-3.

Vanhée,B.,\&Devigne,C.(2018).Differences in collembola species assemblages (Arthropoda) between spoil tips and surrounding environments are dependent on vegetation development. Scientific Reports, 8(1), 1-16. https:// doi.org/10.1038/s41598-018-36315-1.

Wardani, D. K., Darmanti, S., \& Budihastuti, R. (2018). Allelochemical effect of Ageratum conyzoides L. leaf extract on Soybean [Glycine max (L.) Merr. cv Grobogan] growth. Journal of Physics: Conference Series, 1025(1), 012044. https://doi. org/10.1088/1742-6596/1025/1/012044.

Zachariades, C., Day, M. D., Muniappan, R., \& Reddy, G. V. P. (2009). Chromolaena odorata (L.) King and Robinson (Asteraceae). Dalam R. Muniappan, G. V. Reddy, \& A. Raman (Eds.), Biological control of tropical weeds using arthropods. Cambridge: Cambridge University Press. https://doi. org/10.1017/CBO9780511576348.008. 